\title{
A web-based environment for shape analysis of fish otoliths. The AFORO database*
}

\author{
ANTONI LOMBARTE ${ }^{1}$, ÒSCAR CHIC ${ }^{1}$, VICENÇ PARISI-BARADAD ${ }^{2}$, \\ ROGER OLIVELLA ${ }^{1}$, JAUME PIERA ${ }^{3}$ and EMILIO GARCÍA-LADONA ${ }^{1}$ \\ ${ }^{1}$ Institut de Ciències del Mar (CMIMA-CSIC), Passeig Marítim 37-49, 08003 Barcelona, Catalonia, Spain. \\ E-mail: toni@icm.csic.es \\ ${ }^{2}$ Departament d'Enginyeria Electrònica, Universitat Politècnica de Catalunya (UPC), Barcelona, Catalonia, Spain \\ ${ }^{3}$ Unitat de Tecnologia Marina (CMIMA-CSIC), Passeig Marítim 37-49, 08003 Barcelona, Catalonia, Spain.
}

\begin{abstract}
SUMMARY: We present an automatic system for describing and identifying fish otolith shapes combining information technologies with modern advances in signal analysis. As a major novelty with respect to past studies the system includes wavelets (WT) and curvature space scale (CSS) analyses that have been shown to provide local morphologic information and characteristics (landmarks) of the sagitta otolith outline for non-specialists. By applying this electronic catalogue directly the system is very helpful for determining teleostean fish size, population and species. Both the electronic catalogue and the shape analysis are implemented through the AFORO database, which at present contains more than 1250 high resolution images of the left sagitta from 292 species and 94 families of teleostan fishes sampled mainly in Mediterranean and Antarctic waters.

Keywords: otolith, shape analysis, Curvature Scale Space, Wavelets, Fourier.

RESUMEN: UN SISTEMA DE ANÁLISIS DE LA FORMA DE LOS OTOLITOS DE PECES BASADO EN INTERNET. LA BASE DE DATOS AFORO. - Se ha elaborado un sistema automático que describe e identifica las formas de otolitos de peces a partir de la combinación de tecnologías de la información y modernos avances en análisis de señal. Respecto a otros sistemas, éste presenta como principal novedad el uso de análisis de formas basados en la aplicación de wavelets (WT) y análisis de la curvatura a diferentes escalas (CSS). Estos análisis proporcionan información local de las características morfológicas del contorno externo del otolito de forma automática, facilitando la labor de identificación a no especialistas en morfología de otolitos. Una aplicación directa de este sistema facilitará la determinación del tamaño, la población y la especie en peces Teleósteos. Ambos, el sistema de análisis de formas y el catálogo de otolitos se implementan en la base de datos AFORO, que incluye actualmente, más de 1250 imágenes de alta resolución de otolitos pertenecientes a 292 especies y 94 familias de peces Teleósteos, procedentes básicamente del mar Mediterráneo y del océano Antártico.
\end{abstract}

Palabras clave: otolitos, análisis de forma, análisis de curvatura, Wavelets, Fourier.

Otolith shape analysis is a way of providing information on species (Schmidt, 1969; Nolf, 1985), phylogeny (Lombarte and Castellón, 1991), their ecobiological parameters (Platt and Popper, 1981; Morales-Nin, 2000) and geographic origin (Castonguay et al., 1991; Campana and Casselman, 1993). The sagitta otolith shape variability has been

*Received June 29, 2005. Accepted September 13, 2005. related to genetic, ontogenetic and environmental factors (Lombarte et al., 2003). Their species-specific shape properties have been used in stomach content studies of marine ictiophagous species (Fitch and Brownell, 1968), and in descriptions of fossil fauna (Nolf, 1985) to determine species composition. Ontogenetic otolith shape changes during fish growth have been described and used to identify age in commercial species (Cardinale et al., 2004), and 
sex and maturity stage (Piera et al., 2005). Therefore, it is possible to conclude that an automatic system able to describe and identify otolith shapes can be of general use for sex, age, population and species identification studies, as well as provide necessary and relevant information in ecological studies. Thus, in this note we present a fish otolith database connected through an interactive web system that is able to characterize fish otolith shapes by applying modern analysis techniques (Parisi-Baradad et al., 2005), to the contour points represented in $\mathrm{x} / \mathrm{y}$ co-ordinates (Piera et al., 2005).

The whole system, called generically AFORO (in the Catalan language the acronym for shape analysis of fish otoliths) is composed of a database of highresolution fish otoliths with complete morphometric information, and a shape analysis module that provides mathematical descriptors of the otolith shapes. The database was developed using the PostgresSQL Data Base Management System (Worse and Drake, 2002) and includes four tables:

1. Donor fish information including fish identification, fish length type (total length, standard length, etc.), fish length in $\mathrm{mm}$, age, sex, taxonomic information (species) and date and location of sampling.

2. Otolith information identified by an ID code, otolith type (sagitta, asteriscus, lapillus), side (left, right), information type (whole otolith, otolith sections), anatomical position (distal, proximal). The otolith information is linked to the donor fish table with a 1 to $\mathrm{N}$ relation.

3. A results table concerning the otolith image which includes: analysis type, morphological data type, data format and description, URL of a metadata file containing the source of information: some keywords, the person who gave the sample and the institution to which they are affiliated. This information is also related to the previous otolith information table by a 1 to $\mathrm{N}$ relation.

4. Finally, a contact table including the information of the person who processes the data sample. This table is related to the otolith information table by a one to one relation.

At present, the image database contains a total of 1250 high resolution images of left sagitta otoliths corresponding to 292 species and 94 families mainly from the western Mediterranean and Antarctic Seas (Weddell Sea and Antarctic Peninsula), and several samples from Benguela (Namibia), east Atlantic (Senegal), the mouth of La Plata River (Uruguay) and the northeast Atlantic.
Otolith shape analysis is based on three main mathematical descriptors related to the one-dimensional decomposition of the otolith contours: Fourier spectrum (FFT), wavelet analysis (WT) and a curvature scale space analysis (CSS). The FFT method is based on a harmonic decomposition of the contour shape and has been used in the past as a way of characterizing otolith contours (Bird et al., 1986; Castonguay et al., 1991; Campana and Casselman, 1993). The WT is based on expanding the contour into a family of functions obtained as the dilations and translations of a unique function known as a mother wavelet (Mallat, 1991). These functions describe both in space and wave number the most prominent features of the curve (sharp transitions). CSS representation is a technique that focuses on finding the curvature changes of a contour (the inflection points) and analyzing how they change after successive smoothing of the curve (Mokhtarian and Mackworth, 1992). Both WT and CSS have been shown to be more effective for characterizing otolith shape than FFT, as they are able to localize in space both global and local features of the contour intuitively, which is more closely related to the way a human operator perceives the shape (Parisi-Baradad et al., 2005).

The otolith database, the shape analysis and the description system are all accessible through a webbased environment (http://www.cmima.csic.es/ aforo/), in which a server links the database with the numerical routines to perform different shape analyses (Fig. 1). The web interface has been developed mainly using Java technology (Java Server Pages and Servlets), Javascript and HTML. The interface starts from a search page that looks into the database and supplies a results table after validation. Otolith sample information and its corresponding high-resolution image ( 8 bit depth with 256 grey levels) are accessible by clicking on the otolith ID. Then, you can visualize the image, the extracted contour and the shape analysis of the sample (FFT, WT and CSS), and compare it with other related otolith samples belonging to the same species.

As an example of the way the shape analysis information should be interpreted we have shown the shape analysis for samples belonging to several species (Fig. 2) and for a single species (Fig. 3). As we can see, the implemented shape analyses (FTT, WT and CSS) are sensitive to the main morphological characteristics of each otolith outline and each otolith typology has a differentiated numerical description. Some differences between the analyses in 


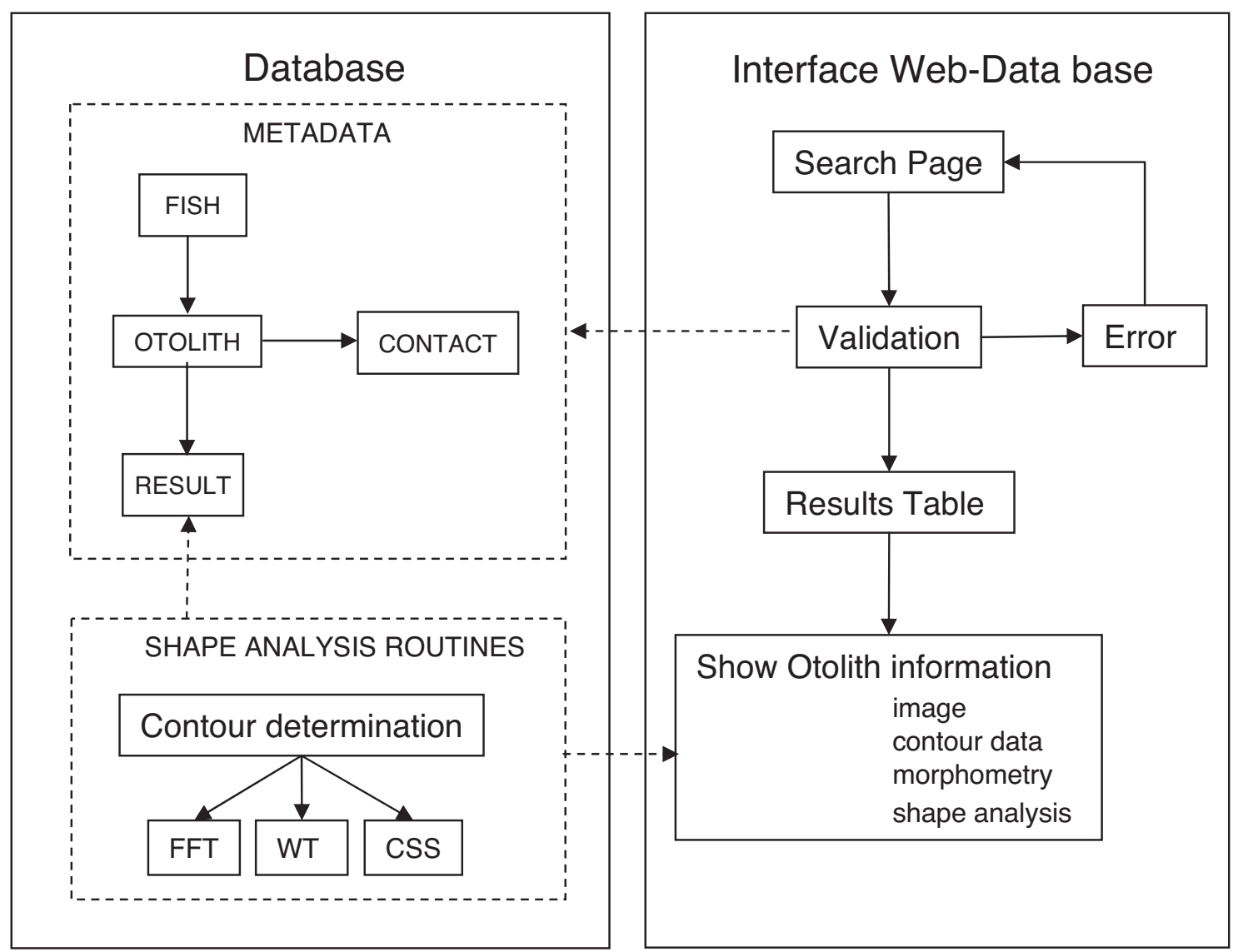

FIG. 1. - Structure and relationships of the web-based interface AFORO including the electronic catalogue of otolith images and the shape analysis: Fast Fourier Transform (FFT), Wavelet spectrum (WT) and Curvature Scale Space (CSS).

the process of describing the otolith contour can be observed. When different typologies of otolith shape are compared, the main morphological differences can be inferred from the graphic representations of the WT and CSS analyses. As an example, the trilobated otolith of Zeus faber showed three areas of maximum morphological singularity which clearly represented the characteristic otolith of this specie. In other cases, Mullus barbatus showed an area of maximum variability at the exisura ostium notch, in Sarda sarda the maximum variability area was located on the elongated rostrum, and Umbrina cirrosa, who have a sagittta characterized by a circular shape, did not show areas of high morphological variability. Not only is the number of maximum variability areas important for differentiating species, but also their spatial location (Fig. 2). Thus, both multiscale analyses (WT and CSS) clearly identify single morphological points (landmarks) located on the $\mathrm{x}$-axis along the contour where the rostrum is the origin of the contour. In contrast, by looking at the FFT spectra it is not obvious how the landmarks are related to the shape and it is not possible to locate where the most prominent features are located.
The implemented analyses can also help to identify size and therefore age of specimens based on the alometric changes produced during otolith growth. Again, using multiscale analysis can be helpful to show local changes in the otolith outline, in this case otolith samples belonging to different sized specimens of Merluccius merluccius (Fig. 3). As the specimen grows the whole otolith shape undergoes small changes that are only faintly apparent at small scales. The small otoliths of Merluccius spp. are characterized by a sinuated margin sculpturing (Smale et al., 1995) in the dorsal and ventral margin. In medium sized fishes, the ventral margin of their otoliths become smooth. Finally, the biggest specimens are characterized by a generally smooth dorsal and ventral margin, altered by deep and narrow indentations in the dorsal margin. These local changes in the outline margin during growth can be easily observed in the multiscale analysis systems. For this reason, using the multiscale system is an improvement in the study of ontogenetic changes in relation to non-local shape analysis, such as FFT used in previous studies (Morales-Nin et al., 1998; Cardinale et al., 2004). 


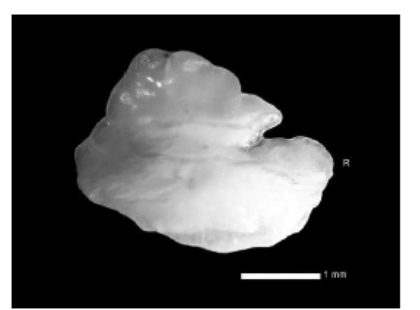

Mullus barbatus (ovate)
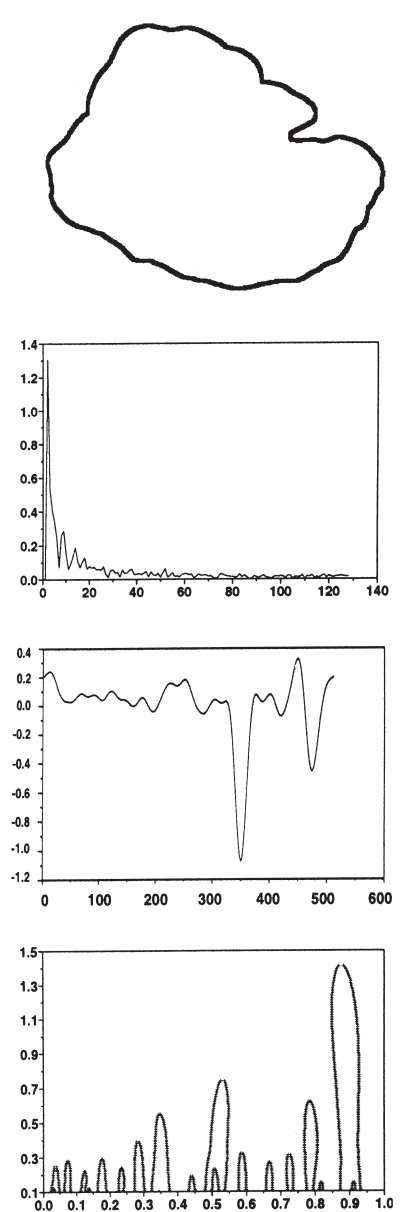

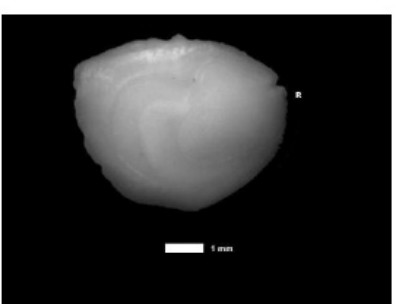

Umbrina cirrosa (circular)
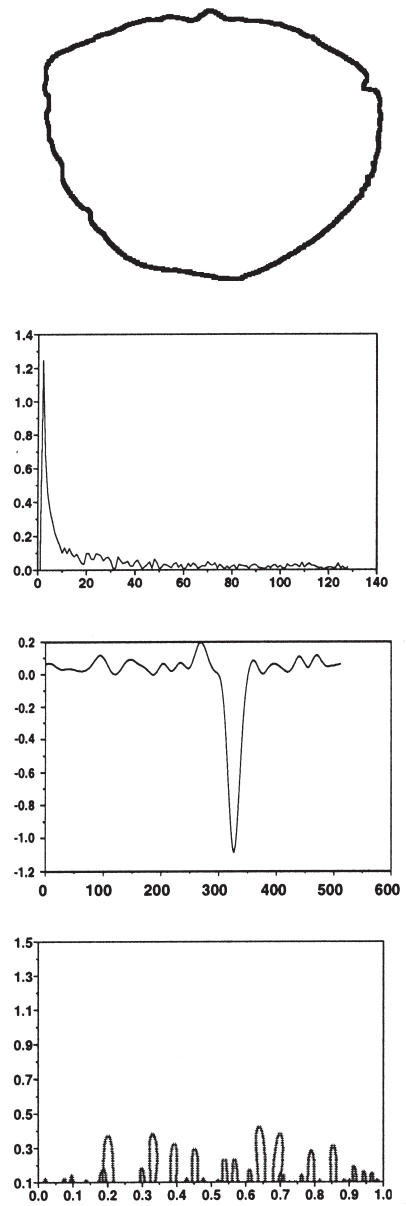

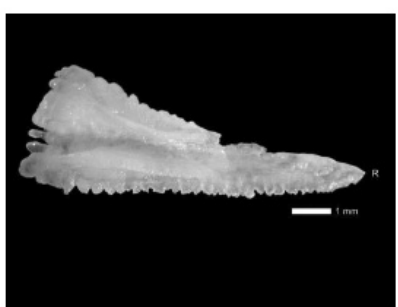

Sarda sarda (pyriform)
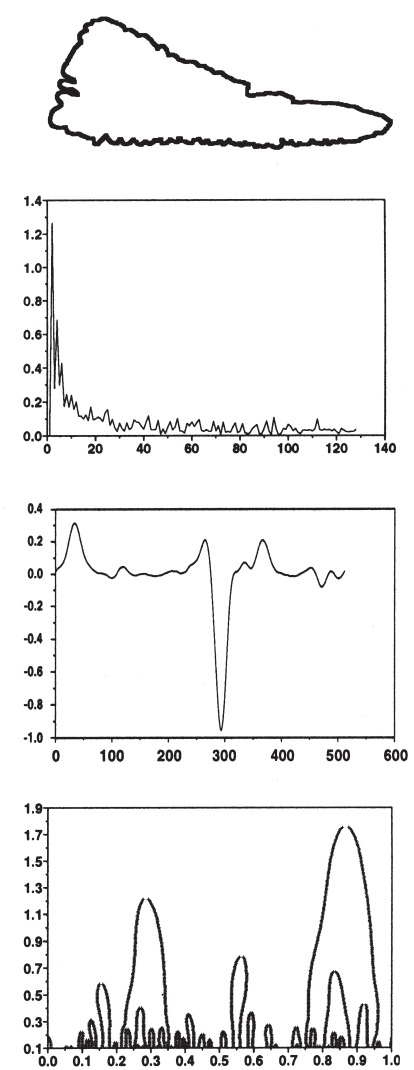

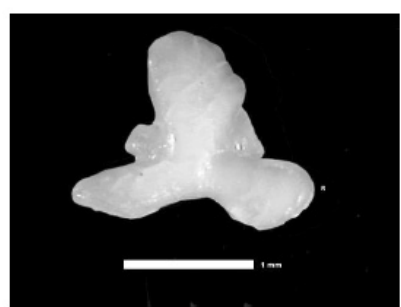

Zeus faber

(trilobate)
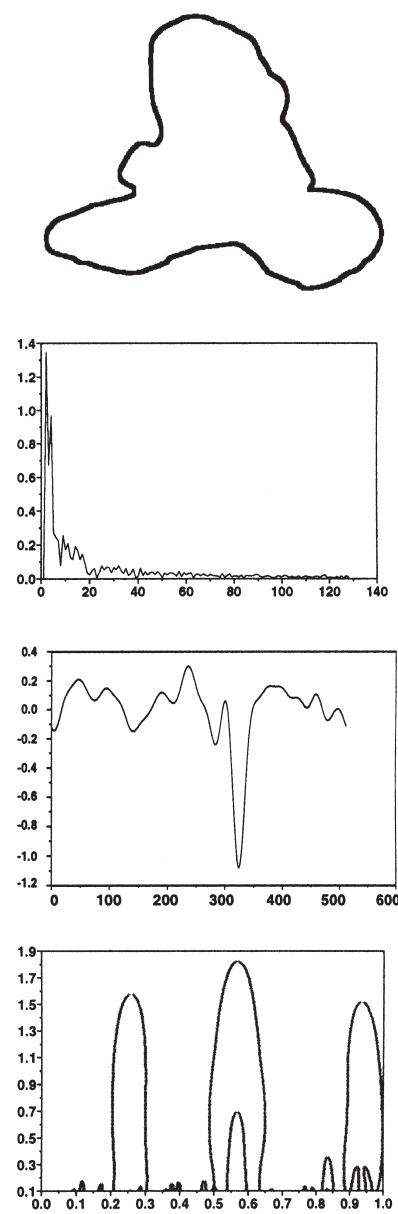

FIG. 2. - Otolith images from different Mediterranean species (Mullus barbatus, Umbrina cirrosa, Sarda sarda and Zeus faber) included in the AFORO database. The shape analysis is given on a dimensional representation of the contour sampled clockwise from the rostrum (the rightmost point of the contour). First row: high resolution images of sagitta otoliths. Second row: contours extracted from the corresponding images. Third row: Fast Fourier Transform spectrum, the horizontal axis corresponds to the wavenumber of each harmonic. Forth row: Wavelet analysis at the third scale, the horizontal axis corresponds to the sampled contour points, all contours are sampled to a total of 512 points; Fifth row: Curvature Scale Space analysis, the horizontal axis corresponds to the total length of the contour normalized to the interval $[0,1]$ (details of each representation can be found in Parisi-Baradad et al., 2005).

In summary we have presented how the combination of emerging information technologies with recent advances in signal analysis provides a system that can be very useful for determining fish size, age range, population or species from an electronic catalogue of fish otolith shape characterization. In particular, WT and CSS analyses have been shown to provide local morphological information and char- acteristics (landmarks) of the sagitta outline for nonspecialists.

\section{ACKNOWLEDGEMENTS}

This work has been supported by the Spanish MICYT TIC2000-0376-p4-04 project. The authors 


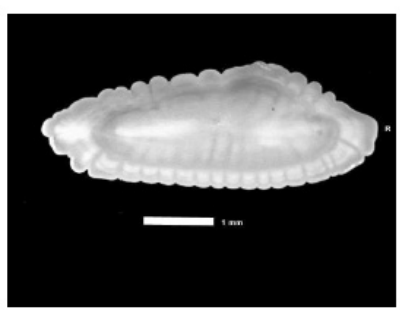

$10 \mathrm{~cm}$
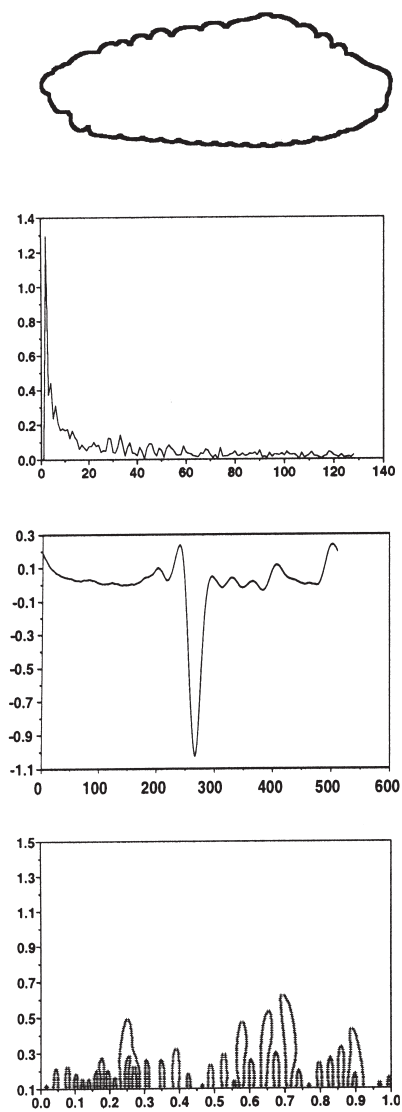
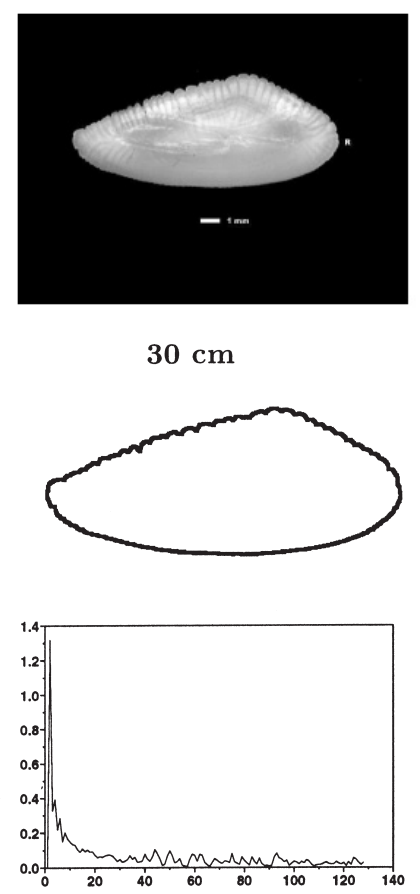

$30 \mathrm{~cm}$
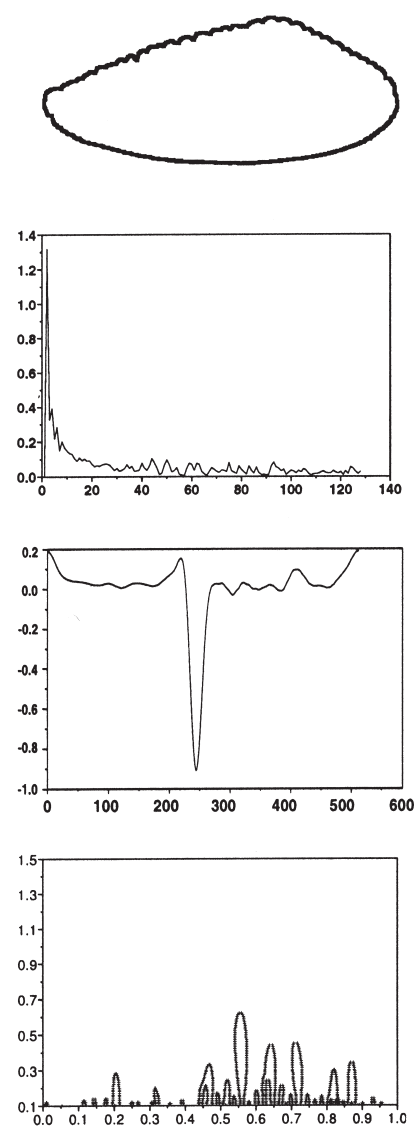

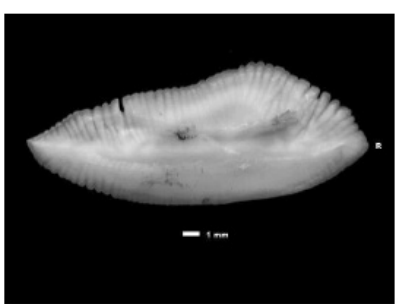

$50 \mathrm{~cm}$
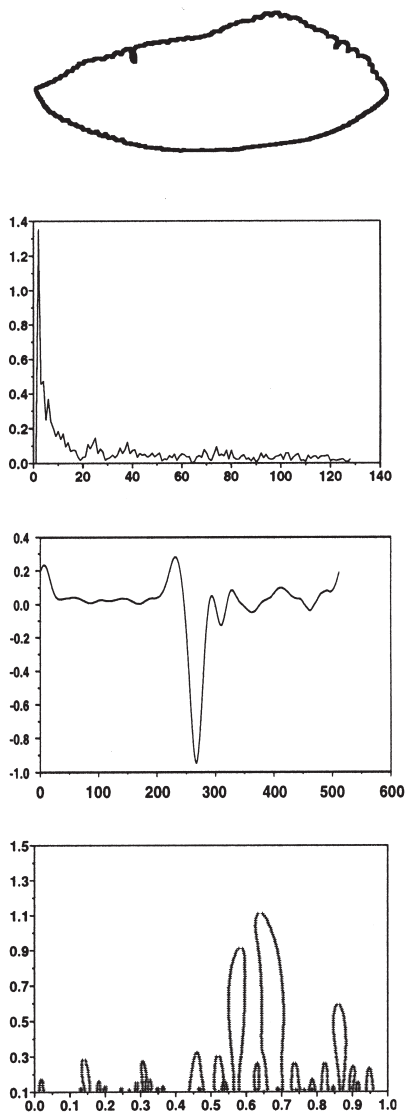
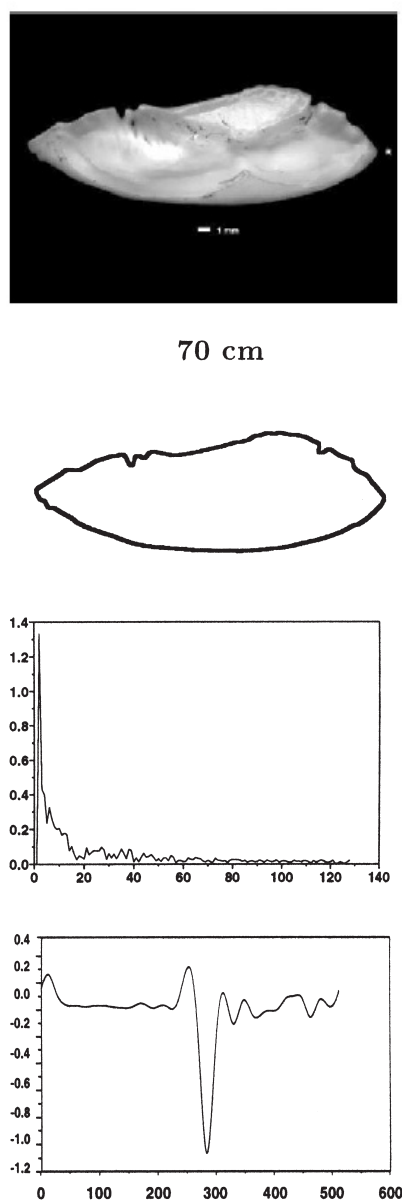

$70 \mathrm{~cm}$
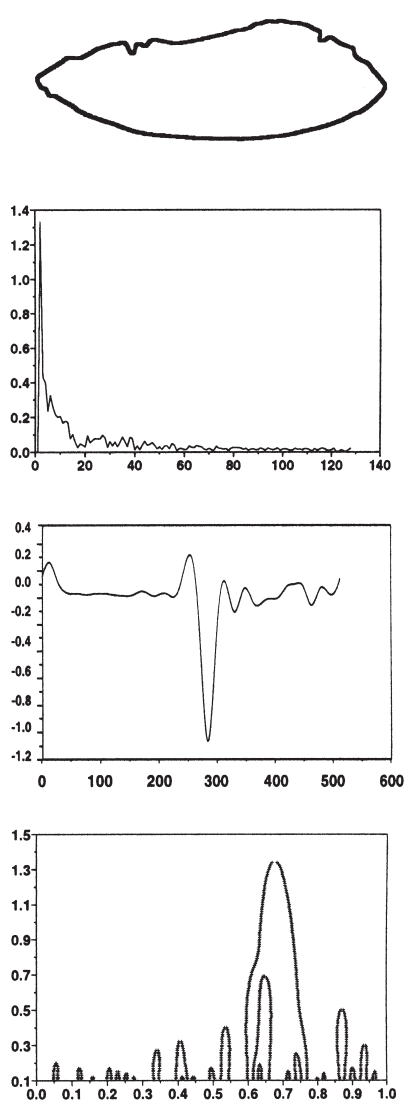

FIG. 3. - Otolith images from the AFORO database of several samples of Merluccius merluccius of different sizes. The shape analysis is equivalent to Figure 2.

wish to thank Laura Recasens, Beatriz MoralesNin, Montserrat Demestre, Paloma Martín, Joan Moranta, Pilar Sánchez, Francesc Sardà, Joan B. Company, Joan Cartes, Montserrat Ramón, Domingo Lloris from CSIC, Ana Ramos, Enric Massutí from IEO, Walter Norbis from INAPE (Uruguay), Wolf Arntz from AWI (Germany), Dirk Nolf from the Institute Royal des Sciences Naturelles of Belgium, Coral Hispano from the Barcelona Aquarium and Clara Coll for supplying a great part of the otolith samples included in the AFORO database. We also thank Antonio Cruz, Evilio del Río and Rosa Vitrià for their technical support in developing the project.

\section{REFERENCES}

Bird, J.L., D.T. Eppler and D.M. Checkley. - 1986. Comparison of herring otoliths using Fourier series shape analyses. Can. J. Fish. Aquat. Sci., 43: 1228-1234.

Campana, S.E. and J.M. Casselman. - 1993. Stock discrimination using otolith shape analysis. Can. J. Fish. Aquat. Sci., 50: 10621083.

Cardinale, M., P. Doering-Arjes, M. Kastowsky and H. Mosegaard. -2004 . Effects of sex, stock, and environment on the shape of known-age Atlantic cod (Gadus morhua) otoliths. Can. J. Fish. Aquat. Sci., 61: 158-167.

Castonguay, M., P. Simard, and P. Gagnon. - 1991. Usefulness of Fourier analysis of otolith shape for Atlantic mackerel (Scomber scombrus) stock discrimination. Can. J. Fish. Aquat. Sci., $48: 296-302$.

Fitch, J.E. and R.L. Brownell. - 1968. Fish otoliths in cetacean stomachs and their importance in interpreting feeding habits. $J$. Fish. Res. Bd Can., 25: 2561-2574.

Lombarte, A. and A. Castellón. - 1991. Interespecific and intraspe- 
cific otolith variability in the genus Merluccius as determined by image analysis. Can. J. Zool., 69: 2442-2449.

Lombarte, A., G.J. Torres and B. Morales-Nin. - 2003. Specific Merluccius otolith growth patterns related to phylogenetics and environmental. J. Mar. Biol. Ass. U.K., 83: 277-281.

Mallat, S. - 1991. Zero crossings of a wavelet transform. IEEE Trans. Inform. Theory, 37: 1019-1033.

Mokhtarian, F. and A.K. Mackworth. - 1992. A Theory of MultiScale, Curvature-Based Shape Representation for Planar Curves. IEEE Trans. Pattern Analysis Mach. Intellig., 14 : 789-805.

Morales-Nin, B. -2000 . Review of the growth regulation processes of otolith daily increment formation. Fish. Res., 46: 53-67.

Morales-Nin, B., A. Lombarte and B. Japón. - 1998. Approaches to otolith age determination: image signal treatment and age attribution. Sci. Mar., 62: 247-256.

Nolf, D. - 1985. Otolith piscium. In: H.P. Schultze (ed.), Handbook of paleoichthyology, 10. pp. 1-145. Gustav Fisher Verlag, New York.

Parisi-Baradad, V., A. Lombarte, E. García-Ladona, J. Cabestany, J. Piera and Oे. Chic. - 2005. Otolith shape contour analysis using affine transformation invariant wavelet transforms and curvature scale space representation. Mar. Freshw. Res., 56: 795-804.

Piera, J., V. Parisi-Baradad, E. García-Ladona, A. Lombarte, L. Recasens, and J. Cabestany. - 2005. Otolith shape feature extraction oriented to automatic classification with open distributed data. Mar. Freshw. Res., 56: 805-814.

Platt, C. and A.N. Popper. - 1981. Fine structure and function of the ear. In: W.N. Tavolga, A.N. Popper and R.R (eds.), Hearing and sound communication in fishes. pp. 3-38. Springer-Verlag, New York.

Schmidt, W. - 1969. The otoliths as a means for differentiation between species of fish of very similar appearance. Proc. Symp. Oceanog. Fish. Res. Trop. Atl., UNESCO, FAO, OAU. 393-396.

Smale, M.J., G. Watson and T. Hetch. - 1995. Otolith atlas of southern African marine fishes. In: Ichthyological Monographs of the J.L.B. Smith Institute of Ichthyology, 1: 1-244.

Worsley, J.C. and J.D. Drake. - 2002. Practical PostgreSQL. O'Reilly, Sebastopol, USA.

Scient. ed.: B. Morales-Nin 